\title{
DEVELOPING A COMPREHENSIVE MODEL FOR FORTHCOMING REFORMS OF UNIVERSITY HOSPITALS
}

\author{
*Māra Pētersone ${ }^{1}$, Kārlis Ketners² ${ }^{2}$ Dainis Krieviṇš ${ }^{3}$, Ilze Kreicberga ${ }^{4}$, Ingars Eriṇš ${ }^{5}$ \\ ${ }^{1}$ Dr.oec., Senior researcher, Riga Technical University, Kalnciema str.6, LV-1048, Latvia; \\ E-mail: mara.petersone@rtu.lv \\ ${ }^{2}$ Dr.oec., Prof., BA School of Business and Finance, Kr.Valdemara str.161, LV-1013, \\ Latvia;E-mail: karlis.ketners@ba.lv \\ ${ }^{3}$ Dr.med., Prof., Paula Stradina Clinical University Hospital; Pilsonu str. 13, LV-1002, \\ Latvia; E-mail: dainis.krievins@stradini.lv \\ ${ }^{4}$ Dr.med., Chairman of the Board, Paula Stradina Clinical University Hospital; Pilsonu str. \\ 13,LV-1002, Latvia; E-mail: ilze.kreicberga@stradini.lv \\ ${ }^{5}$ Dr.oec., Prof., Riga Technical University, Kalku str.1, LV-1050, Latvia; E-mail: ingars.erins@rtu.lv
}

Received 2805 2019; Accepted 30062019

This paper is devoted to developing institutional arrangements viable for forthcoming reforms of university hospitals in Latvia. The aim of the article is to provide a Latvian university hospital governance approach, taking into consideration the regulation of state-owned enterprises and its relevance for public hospitals. Comparative analysis was used examining the significant factors for institutional arrangements of university hospitals to be considered during future developments based on the research of relevant legislation, policy documents, OECD reviews and WHO's evaluations. Proposals for semi-autonomous hospital governance improvement by the creation of a Supervisory Board and a new organizational form of hospitals were developed. The necessity of future research for creation of regional healthcare network organisations for Latvian healthcare system was considered.

Keywords: state-owned enterprises, hospital organizational models, governance, public hospitals, healthcare system.

JEL Code: I18; H11; H75; L2O.

\section{Introduction}

The management of modern healthcare is becoming increasingly complex. Many countries are exploring organisational models which help to improve hospital governance, change the day-to-day governance of hospitals and healthcare institutions. In recent years, the interest in the organizational side of the healthcare system has increased significantly. The challenge faced by researchers, practitioners and policymakers is to identify ways how to improve healthcare as such by enhancing the management of organizations that provide this care, taking into consideration the complexity of healthcare organizations.

Copyright (C) 2019 The Authors. Published by Vytautas Magnus University, Lithuanian Institute of Agrarian Economics. This is an open-access article distributed under the terms of the Creative Commons Attribution-NonCommercial 4.0 (CC BY-NC 4.0) license, which permits unrestricted use, distribution, and reproduction in any medium, provided the original author and source are credited. The material cannot be used for commercial purposes. 
Bennington (2010) reviewed both theoretical and empirical research of business and healthcare management to determine the state of knowledge that can confidently guide those who perform board roles as well as who create governance structures and concluded that further research is necessary to take into account the complexity of the healthcare sector. In Scholten and Van der Grinten (2002) corporate governance policy was reviewed with the aim of integration of medical specialists in hospitals. Mettler and Rohner (2009) analysed healthcare business management demand for double university degree holders required at an executive level at a university hospital. Laffel and Blumenthal (1989), Hearld et.al. (2008), Qureshi et. al. (2003) found out that the management of hospitals required comprehensive clinical and business management knowledge as well as excellent scientific skills. Scientific skills are important for the reason that such a leader can perform a good problematization process. Current knowledge is based on general business governance theory and practical experience in hospital management. Scientific literature also discusses several aspects of hospital management in cases when there is a change in the healthcare system in the sense of moving away from a centrally regulated system to decentralized profit and non-profit organisations (Barnett, et.al., 2001, Pirozek et.al., 2015). However, a university hospital is a multi-profile in-patient institution that provides secondary and tertiary healthcare services to patients, participates in the implementation of the bachelor's, master's, resident's and doctoral study programs, performs scientific and research work in the field of medicine and promotes the introduction of new therapeutic methods and medical technologies. As university hospitals' functions include highly qualified healthcare, medical education, science and healthcare system functioning, the support requirements for decision making and organisational structure will differ from other state-owned enterprises and even from other level hospitals. Latvian state-owned enterprises (SOEs) are subjects of scientific research in terms of legal framework and organization of public entity (Saulitis, 2013) or in the field of governance issues (Jevcuka and Ketners, 2011) in general. Healthcare SOEs are subjects of research in very few specific cases such as application of process management to hospitals (Barzdins et. al., 2015) or management of corporate identity for healthcare providers (Rutitis et. al., 2012). However, there has been no research done on university hospitals' management and organization in the Latvian healthcare system as most of the theory on them is derived directly from the industry. This would open new opportunities for scientifically interested practitioners to add new management articles to the literature. Ideas for applying such a scientific approach, combined with aspects based on practical experience, have great potential for scientists to create new management theories and models suitable for healthcare. One of the specific scientific problems for Latvia is corporate governance of healthcare SOEs through the organization of executive management of hospitals and the allocation of decision rights of state-owned enterprises in Latvia. The aim of this article is to investigate worldwide guidelines in the field of corporate governance of state-owned hospitals, to identify key determinants of the hospital behaviour and to propose institutional arrangements for Latvian university hospitals taking into consideration the Latvian regulation of state-owned enterprises and its relevance for public hospitals, 
identifying the primary areas of improvement and providing practical suggestions for further actions, paying due consideration to relationships between public-sector decisionmaking and hospital-level organizational behaviour.

\section{Research methodological approach}

Inductive research methodology and case study were implemented looking at university hospitals as an entity with business and non-profit healthcare and health service quality goals, taking into consideration scientific literature, secondary data of Latvian National Health Service reports and interviews with stakeholders to generate possible solutions for university hospital governance improvements. Based on relevant international experience, legislation, policy documents, the Organisation for Economic Co-operation and Development (OECD) reviews and World Health Organization's (WHO) evaluations, comparative analysis of suitable organizational form was carried out, examining the elements of the problem and the findings based on the course of research.

The analysis from the case studies shows that the main issue in university hospitals is the lack of integration of national-level decisions and governance decisions on the hospital level. Hospitals are part of general government and, despite the organizational issues, are subject to public sector regulation, and since they provide services of public interest, hospital corporatization, autonomy and even privatization are being considered and applied to improve performance of public health services institutions in Latvia. In case of Latvia state hospitals are main in-patient care providers and financed from state budget subsidies, while total annual own resources constitute 21754636 euros, budget funding received is 249914313 euros (See Cross-sectoral coordination centre, 2019). When analyzing the operation of healthcare institutions in Latvia, it is worth noting that nine healthcare institutions account for more than two-thirds of all hospital admissions, and Riga Eastern Clinical University Hospital is the leading in-patient service provider in Latvia, accounting for about $20 \%$ of total activity. Paula Stradina Clinical University Hospital is the second largest service provider covering $11 \%$ of all activities. There is evidence that large-scale hospitals and their surgeons deliver better results than institutions or doctors with fewer activities in different medical conditions and procedures.

State budget financing in case of Latvia is in form of National Health Service healthcare purchasing contracts, this leads to the main objective of the transformation of reforming of the funding and payment arrangements for state hospitals to address problems of transparency, efficiency, quality, and productivity. As shown in the literature (See Harding, A. \& Preker, A.S., 2000) problems of efficiency and productivity of healthcare service SOEs traditionally (are solved by changing the structure of funding or payments to providers. Changes in payments system reinforce the link between resource allocation and achieving results of providing health care. Based on Harding, A. \& Preker, A.S., 2000 and Kuhlmann, E. et.al., 2016 as examples are a retrospective fee for service, 
per diem, or case-based payments. Some reforms try to promote efficiency by shifting the risk of expenses to health care service providers through payments or predictable global budgets. During the last decade in the financing and payment systems, a variety of structural changes are carried out to eliminate concerns about clinical or consumer quality. The main goal of such changes is a reinforcement of the link between choice of patients or purchaser of services (e.g. National Health Service) and service providers. Examples are fundholding with patient selection, limited or fully competitive contracting with providers and demand subsidies (health vouchers to be used with providers or insurers). However, payment reforms such as automatization and corporatization can be used to address problems in the cost-effective use of public resources.

In this context, it is necessary to delink the funder (state institution under the supervision of Ministry of Health) from the provider (entity with main stakeholder Ministry of Health) in order to break the "provider capture", characteristic of payment systems that allocate resources to hospitals and doctors rather than to services or individuals. This allows hospitals' organizational structure splitting day-to-day management, payments and strategic management of state assets from service provision management, thus significant efforts can improve the knowledge of healthcare sector managers, both by training existing staff and by making changes to human resource management policies, in order to focus on management skills. On the basis of empirical research, it could be summarized that the main tasks for sustainable hospital governance development are the sustainability of the network in the context of changing sociodemographics, procurement and effective use of expensive medical equipment. It is impossible without decentralization of governance and autonomy of decision-making based on a common vision, healthcare policy and assurance of continuity of processes regardless of government changes.

A typology of effective stewardship and management features provides a systematic, theoretically grounded way how to address government and management issues, and would serve as guidelines for building, maintaining and evaluating successful partnerships. It offers a multidisciplinary perspective for classifying important organizational issues, identifying obstacles to successful development and sustainability and promoting achievement of goals.

\section{Literature review on state-owned enterprises institutional arrangement and health care as particular case}

As stated by Christiansen (2011), SOEs and similar entities form a significant part of the corporate economy. After the decade of the privatization process, the concentration of the remaining corporations in several sectors of the national economy is very high. Nearly half of all SOEs (in terms of value) in OECD countries are located in the network sectors, mostly transportation, power generation and other energy. A fourth of total valuation is accounted for by financial institutions. In addition, there are many partially privatized telecommunications companies among the partially stateowned listed companies. In essence, not only the state-owned enterprises are important 
to national economies, but it is also important that SOEs are concentrated in some "strategic" sectors and have a significant impact on the competitiveness of other business sectors. Research of state-invested enterprises SOEs is described in the scientific literature (Aharoni, 1986; Goldberg et. al., 2008; Toninelli, 2000). However, most existing theories of the firm historically have been developed in the United States (US), but SOEs sector is covered partially. Most theories of the firm are based primarily on the research of private enterprises whose main goal is to maximize profits. However, such an assumption may not always apply to SOEs, so SOEs remain largely outside existing theories of the firm. As shown in Stan and Bruton (2013), existing theories of the firm do not use a significant component of the global economy - SOEs. However, there is demand for organizational form for SOEs. Peng et. al. (2016), analysing existing theories of the firm that form the pillars of the management discipline, largely ignore the theoretical differences that SOEs introduce into the conceptualization of the firm. Therefore, Peng et. al. (2016), extended the four core theories of the firm by incorporating SOEs as a mainstream (not special or marginal) organizational form into these theories. The authors believe that focusing on property rights theory, transaction cost theory, agency theory, and resource-based theory it is possible to develop these theories in the SOEs context. Existing theories of the firm can be extended to create a testable proposal with a focus on SOEs. A comprehensive literature review concluded that contemporary SOEs are not necessarily "state-owned and state-controlled" entities. Instead, in SOEs there can be substantial separation of ownership and control in the meaning that these firms may become "state-owned" and "manager-controlled" (if SOEs managers enjoy significant autonomy) or "state-owned" but "private-controlled" (if control rights are leased to private firms) (Peng et. al., 2016; Cuervo-Cazurra et. al., 2014; Jiang et. al., 2015). The difference between SOEs and non-SOEs is noticeably unclear (Bruton et. al., 2015). In economic theory (Kovacic, 2017), competition, not the type of ownership, is decisive to an enterprise's performance and efficiency. Competition is the key determinant of an SOE's performance, as it is of a privately-owned enterprise. The ability of an enterprise to operate efficiently and compete depends on its corporate governance - on how ownership and control rights in an enterprise are exercised. International experience has shown that it is difficult to design governance arrangements that could effectively insulate SOEs from political interference, mitigate the dangers of regulatory capture, corruption and non-competitive practices, and compel them to operate efficiently and to innovate (Castaneda et. al., 2008; Duggan, 2000; Kessler et. al., 2002). How healthcare SOEs governance can ensure performance objectives and a suitable governance approach which takes into consideration the specifics of the sector is described by Saltman et. al., 2011. Authors agree with Saltman et. al., 2011 that state that for hospital governance to be effective, it must include national healthcare policy and objectives, which are political and subjective and value-based on macro level. On the other side operational hospital management, which is technical and objective, with a performance that can be measured both clinically and financially. 
Based on Fidler et. al. (2007), the authors summarized key determinants for institutional arrangements of hospitals to be considered in the course of future development of the institutional organization (see Fig.1).

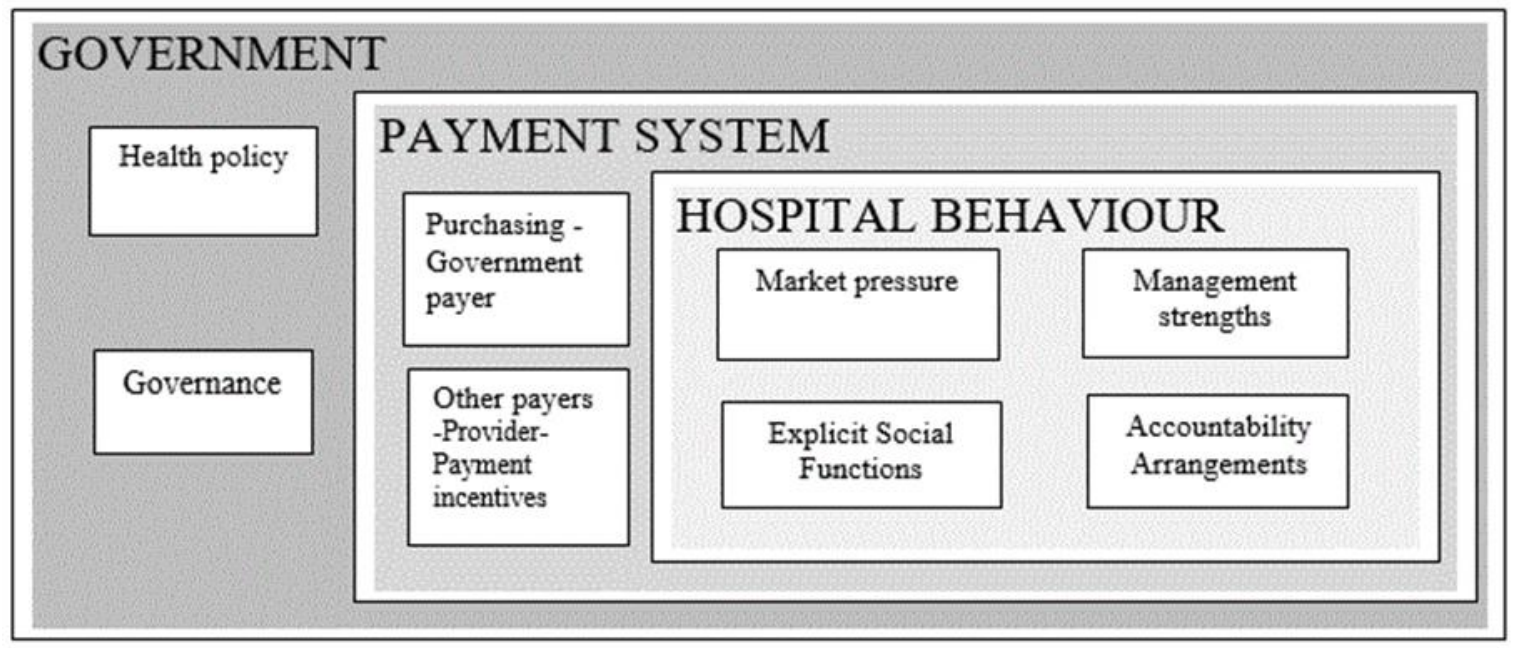

Fig. 1. Key determinants of the hospital behaviour (Source: created by the author (based on Fidler et. al. (2007))

Based on Fidler et al. (2007), the authors also summarized significant factors for institutional arrangements of university hospitals to be considered during future developments (see Fig. 2).

Accountability

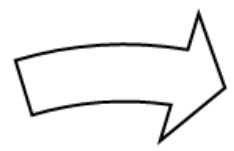

framework and

hospital sector

reforms

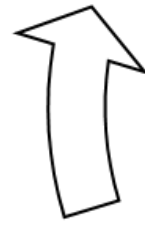
Autonomy \&
Managerial
instruments

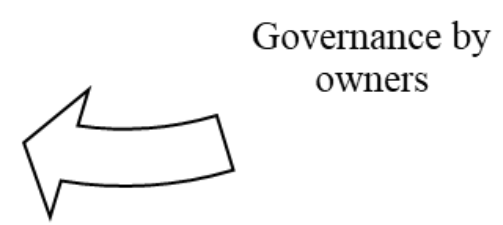

Fig. 2. Institutional arrangement factors (Source: created by the author (based on Fidler et. al. (2007)) 
External pressures and government oversight factors include healthcare policy framework and hospital sector reforms, social functions and performance, regulatory framework, monitoring and evaluation system (Harding and Preker, 2000). The system of strategic purchasing and external market environment is also crucial - barriers to entry and exit (sector neutral competition, selective contracting, minimum standards and licensing, competitive tendering of selected services), yardstick competition (use of comparative provider performance indicators) and contestability (competition not for market share at any given time period but competition over time). Governance by owners includes separation of policy from the owners' objectives and creation of criteria for management performance, structure of independent supervisory management, monitoring and motivation of management and responsibility for supervising management. The organizational structure as autonomy - decision rights over capital assets, decision rights over labour force, decision rights over managerial instruments and setting user fees - should be considered separately. Accountability issues include accountability instruments between the patients and the hospital (community representation on hospital boards, patient grievance procedures), accountability instruments between the payers and the hospital (contracts with performance objectives, audits, comparative provider performance information), accountability instruments between the owners and the hospital (strategy, community and business leaders' representation on hospital boards) and accountability instruments between the regulators and the hospital (output measures, minimum standards). The main strategic goals for best institutional arrangements are equity in access to healthcare, fairness in financial contribution, efficiency and hospital performance impact on revenues, quality and effectiveness, responsiveness, hospital competition in labour and capital assets markets.

Hospitals in many countries face radical changes in their economic and institutional environment. The question of whether state governance is better than the market governance has been frequently asked but, regardless of the form of ownership, governance is crucial. The authors agree with Bloom et. al. (2009), that institutional autonomy is an important factor for improving the healthcare system and quality of health protection, clinical results and satisfaction of patients. This led to the conclusion that institutional autonomy is a key factor for assessment of reforms of hospital governance. Within hospital governance decision rights could be transferred to hospital management and may include control over strategic management (formulation of institutional objectives), market strategy and sales, financial management, inputs, clinical and nonclinical administration, labour and scope of activities. In practice the organizational forms vary significantly in the amount of autonomy given to the managers, the mechanisms used to generate new accountability and the incentives. Many public hospitals and clinics operate as part of the integrated government structure, as a budgetary organization (i.e., a government department). In that case, the organization mainly included in state budgetary structure and not necessarily deliver services to earn its revenues (entity financing case). Reforms are also characterized by the extent to which responsibility for achieving goals is based on supervision of the 
organization, legal framework of the organization or degree of freedom of contracting within the organization. Partial responsibility is the result of market pressure because the market is seen as a universal mechanism that does not result in a political but arbitrary assessment of the organisation's performance.

Latvian SOEs in general have one of two legal forms: a state-owned joint stock company (JSC) or a limited liability company (LLC). Latvian SOEs governance mainly is based on the Commercial law (CL) and companies in general are overseen by a twotier system of supervisory boards and management boards. The board's duties and liability to act in the interests of the company are defined primarily in the CL. On January 1, 2015 the new Latvian SOEs corporate governance law Local Government Capital Shares and Capital Companies (LGCSCC), entered into force, replacing the former Law on State and Local Government Capital Shares and Capital Companies. The LGCSCC outlines the responsibilities of the government as the owner of state assets, including provisions related to the oversight of corporate governance. The law sets procedures for establishing, reorganization, liquidation or selling of state-owned enterprises, as well as for increasing or decreasing state shares in commercial enterprises. The law also includes provisions on the governance of state-owned and state-controlled enterprises, procedures for determining the portion of SOEs profits to be paid out in dividends, and provisions on remuneration for members of SOEs supervisory boards and management boards. Analysis of the governance of the stateowned enterprises in the Latvian health sector revealed that Latvian healthcare SOEs only partly comply with the OECD guidelines (OECD, 2017). Based on Cross-sectoral coordination centre (2019) data from annual reports it can be concluded that there is no common strategy developed for state and municipal assets governance; therefore, the decisions taken upon state-owned enterprises are often based on immediate necessities and there is no coordination with local and regional hospitals in day-to-day management. The juridical status of a considerable part of the state-owned enterprises does not fully correspond to the nature of their activities, and revision of the stateowned enterprises' list has been postponed for several years, which is one of the main obstacles on a way to effective and transparent governance. Delegation of the state capital holder function to the state secretary of the Ministry of Health of the Republic of Latvia may not ensure the realization of the state owner's function in the most effective way, mostly due to considerable work overload and different fields of competence of the state secretary. Establishment of the supervisory boards in the stateowned enterprises would possibly create different behaviour and reduce the distance between the owner and the management of the enterprise, also splitting the financing and the service purchasing function from the managerial functions. Availability of information on state-owned enterprises is fragmentary, mostly in a form of different informative reports; however, the Cross-Sectoral Coordination Centre of the Republic of Latvia has considerably improved the quality and comprehensiveness of the information over the last few years. A special website with elements of a database was created respecting the rights to access public information (Cross-sectoral coordination 
centre, 2018), thus promoting information transparency. This system also allows analysing the information in various ways by different parameters.

In Latvia in terms of legal form, a hospital has the status of a commercial company that utilizes the two-tier (or German) model, where the executive is made up of the board of directors, and the state secretary of the Ministry represents the political power. The obligation to appoint a supervisory board does not apply, though it is permitted by law. The LGCSCC limits possibilities of including private owners (e.g. universities) and involving them in the governance model. As novelty, an alternative legal form could be proposed - a public-funded organization with the status of a nonprofit organization and with financing by payments for healthcare services, donations, contributions and other economic activities that do not directly involve making a profit (a hybrid form of organization). A supervisory board could be appointed by contributing organizations, particularly the Ministry, city or region, university representatives. Similarly, to research done by Hillman (2005) the authors can conclude that due to public ownership of hospitals in Latvia as also in other transition economies, politicians are often nominated to the boards, which raises the question of their actual contribution to hospital governance. In this context, the authors believe that someone within the supervisory board has to have a medical education to be responsible for the education and research area, but qualifications from non-medical disciplines are necessary for other areas of responsibilities.

Research done by Pirozek et.al. (2015) shows that there was no clear relationship between economic results and corporate governance of hospitals in the Czech Republic after transformation. However, in terms of economic performance, the Czech Republic's hospitals owned by the state, including university hospitals, reported significant losses. On the other hand, medical service enterprises with the legal form of a private commercial company with a majority private owner had positive economic results. As in the case of Latvia, in-patient care services are mainly publicly owned. The state owns university level (multi-profile) hospitals and specialized care (psychiatric care) hospitals, but the owners of regional and local hospitals are local municipalities. In 2017 the Ministry was holding state-owned capital shares in 14 enterprises (with direct effective control in 13 enterprises) - both in multi-profile healthcare institutions providing emergency medical aid, consultations and in-patient services, full examination of patients in so-called specialized hospitals - health institutions which, according to the contract concluded with the National Health Service for state-provided healthcare services according to the Regulations of Cabinet of Ministers and particular contacts with National Health Service (Cabinet of Ministers, 2013), receive financial resources in accordance with the volume of services provided. In 2016-2018 four state-owned university hospitals worked with the average total turnover of 232 million euros and also showed losses of total earnings before tax of 2 476 thousand euros (Cross-Sectoral Coordination Centre, 2017), and negative return on assets of $0.66 \%$ in university hospitals (Cross-Sectoral Coordination Centre, 2017) is comparable with economic performance of other transition economies (see also Pirozek, et.al., 2015). As for Latvian circumstances, the authors hypothesize that in the 
situation of the not-for-profit hospital setting, hospitals' economic performance can be improved through the transformation of governance, taking into consideration organizational factors, including professional education, professional commitment and professional ethics of the senior management team, as well as organizational entrepreneurship and environmental factors. The authors assume that no public hospital may be completely independent, and the maximum goal is to achieve semi-autonomy. Clearly, state ownership and private ownership represent different institutional logics (Bruton et. al., 2010), thus necessitating consideration of SOEs incorporating both state and private ownership as hybrid organizations (Inoue et. al., 2013). One of suggested key features which could be used when transforming Latvian university hospitals could be a hybrid SOEs organizational form (Musacchio and Lazzarini, 2014; Bruton et. al., 2015, Denis et.al., 2015). This organizational form, known as hybrid organizations, "incorporates elements from different institutional logics" (Pache and Santos, 2013). The authors agree that hybrid organizations, when managed well, can harvest legitimacy-enhancing elements of the different institutional logics, and survive and even prosper (Battilana and Dorado, 2010). The first step to ensure the decision-making and accountability framework is creation of the Supervisory Board for university hospitals, which will supervise the activities of the Management Board. Appointment of the Supervisory Board seems to be a good solution for the accountability and strategy implementation purpose. The Supervisory Board will also increase the degree of the overall decision-making autonomy and will be the key factor affecting the output.

The second main determinant of successful hospital management is funding and service purchasing organization at the hospital level and coordination of healthcare provision. The main advantages of the Latvian healthcare institutions are diverse infrastructure, availability of modern technology and highly qualified personnel; the disadvantages are as follows: the decrease in the number of healthcare professionals, especially nurses, and unequal accessibility to healthcare services. As a result, a considerable proportion of people do not visit doctors because of the out-of-pocket payments or long queues, deficiencies in healthcare service rate determination methodology, etc. These factors as well as their considerable negative impact on pursuing objectives of society's health at the state level also determine university hospitals' performance indicators, and it is a challenging task to ensure financial stability and sustainable development.

In case of Latvia, the authors conclude that corporatization with different ownership of local and university hospitals has lead to fragmentation of the system, discoordination of service provision and lack of coordination of procurement and use of expensive medical equipment. Despite previous stages of financial and structural consolidation, there is still capacity in Latvia's healthcare system in terms of infrastructure, equipment, staff and bed occupancy. This puts an expensive burden on the healthcare system. Capacity optimization, apparently, can deliver financial savings in the system, improve service quality, and improve access and satisfaction of 
healthcare consumers. Many changes to the existing healthcare system, infrastructure and human resources will be needed to further improve citizens' demands.

On the semi-autonomous hospital governance level (tertiary (university) hospitals and regional hospitals), the hospital management has to take decisions on structural parameters, such as the hospital's service configuration, number of beds, the structure of in-patient and out-patient services. For principal resource-related questions, such as investment and capital decisions, regional network and National Health Service should be responsible on decisions related to the level of offered clinical services (tertiary /secondary/ district)) and general mapping of services. Since investment capital for large new equipment, renovations and new buildings comes from owner investments and national government contributions (also EU structural fund grants), therefore decision-making process regarding hospital funds and/or bank loans should be initiated by the Management Board, based on hospital's strategic planning then approved by the hospital's Supervisory Board and in some cases approved by the Ministry of Health based on Latvia Healthcare Master Plan or similar policy planning document. For operating capital (day-to-day expenses: personnel expenditures, supplies and services), funding sources related to activity-based state financing and payments for services provided lead to a relatively prominent role of the Management Board throughout the whole process. The healthcare system needs dynamic thinking and responsiveness to local needs. As a solution, it could be proposed that local hospitals collaborate well with other local and tertiary level healthcare providers, including regional hospitals nearby, in seeking efficient ways of providing care at a regional level (See Fig.3). Within collaboration network types of hospitals depending on size, catchment area, and type of care e.g. regional, central, clinical university hospitals, local, special, rehabilitation and finally nursing hospitals should be provided.

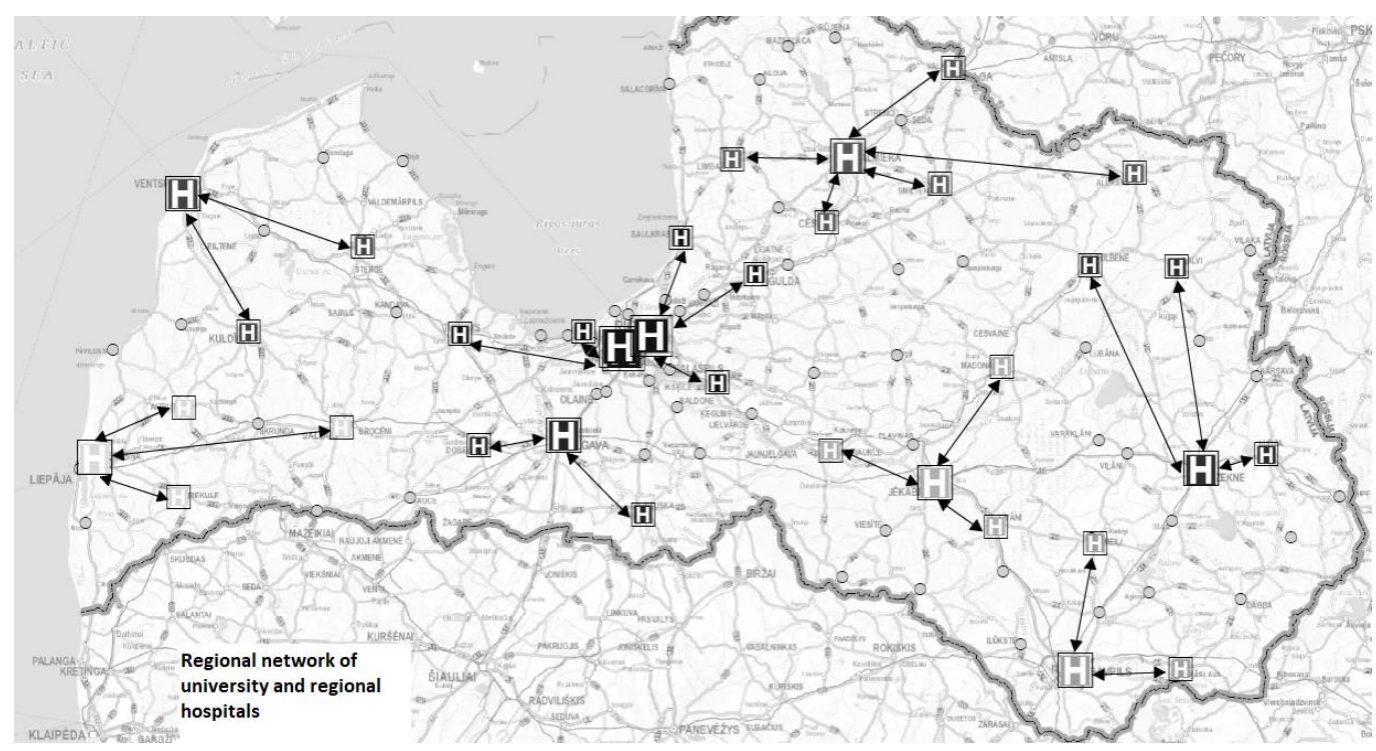

Fig. 3. Regional network system (Source: created by the author (based on National Health Service data and BalticMap.eu) 

The authors agree with Mitchell and Shortell (2000) that public healthcare partnership is voluntary cooperation with various public organizations that have joined together with the aim to improve public health. Although such interdisciplinary cooperation exists, it suffers from governance and management problems associated with inter-organizational relationships in general and in healthcare challenges specifically.

That means that it may be worth considering regional network organisations, such as those in Denmark and Norway (OECD, 2016), on a smaller scale for the Latvian healthcare system. There is also scope for a more systematic network building across the country and more regular sharing of local experiences, successes and challenges. More locally comparable, provider-level data may also help stimulate a dialogue about successes and challenges in different areas of the country. The clinical leaders in university hospitals (main specialist institution) for the priority disease groups should have the possibility to develop disease-specific networking strategy in relation to the hospitals and other healthcare providers.

\section{Conclusions and recommendations}

Management is an important part of cost and quality crisis in healthcare nowadays. However, the positive results at organizations that have adopted the Supervisory Board demonstrate that many of the management problems in university hospitals can be solved. Based on authors summarized significant factors for institutional arrangements of university hospitals to be considered during future developments and to solve national-level health care policy and institutional level decision making in Latvian university hospitals authors recommend establishing the Supervisory Board in university hospitals as a non-executive board for strategic decisions on services provided and investments.

Considering economic and demographic indicators of Latvia, coordination of the hospital sector and creation of regional network organizations under the supervision of tertiary level university hospitals also is crucial at this point. The authors recommend transforming Latvian university hospitals from the stereotypical combination of high levels of state ownership and control and dual nature of the combination of healthcare policy objectives and performance assurance to creation of hybrid organizations that have elements of state ownership and control on the one hand and private approach in day-to-day management on the other hand. As the first step for creation of a hybrid organizational form, a new approach to decision making by supervisory boards is proposed. The research here lays a foundation for further studies with the aim to create a new hybrid organizational form in the Latvian national healthcare sector. For day-today governance purposes, it is necessary to consider recentralization of planning functions at the national level, introduction of a new licensing and monitoring system for healthcare providers regardless of the legal status of healthcare providers as well as creation of the function for the agency within the Ministry of Health tasked with licensing providers and supervising the healthcare system. 
Taking into account the small size of economic regions in Latvia and regional coordination regarding partnerships of different level hospitals, it is proposed to further develop the regional health network. As the next steps of transformation of the Latvian healthcare system, quality management within the regional network should be considered, as the future reform of the organizational form of university hospitals allows hospital boards to shift their focus towards systematic governance of the quality of care.

\section{Acknowledgement}

This work has been supported by the European Regional Development Fund within the Activity 1.1.1.2 "Post-doctoral Research Aid" of the Specific Aid Objective 1.1.1 "To increase the research and innovative capacity of scientific institutions of Latvia and the ability to attract external financing, investing in human resources and infrastructure" of the Operational Programme "Growth and Employment" (No.1.1.1.2/VIAA/2/18/330).

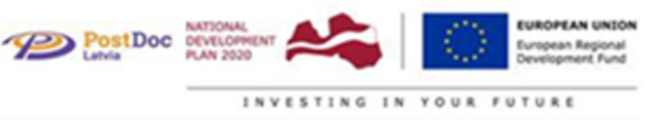

\section{References} Ballinger.

Aharoni, Y. (1986). The evolution and management of state-owned enterprises. Cambridge:

Barzdins, J., Konstante, R., Mitenbergs, U. \& Taube, M. (2015). Transition to hospital process orientation: The case of regional hospitals in Latvia. Journal of Hospital Administration, 5(2), 15.

Barnett, P., Perkins, R., \& Powell, M. (2001). On a hiding to nothing? Assessing the corporate governance of hospital and health services in New Zealand 1993-1998. The International journal of health planning and management, Vol. 16. No. 2: 139-154.

Battilana, J. \& Dorado, S. (2010). Building sustainable hybrid organizations: The case of commercial micro-finance organizations. ACAD MANAGE, 53(6), 1419-1440. doi:10.5465/AMJ.2010.57318391

Bennington, L. (2010). Review of the corporate and healthcare governance literature. Journal of Management \& Organization, Vol. 16. No. 2: 314-333.

Bloom, N., Propper, C., Seiler, S., \& Van Reenen, J. (2009). Management practices in hospitals. Manuscript, London School Econ.

Bruton, G. D., Ahlstrom, D. \& Li, H. L. (2010). Institutional theory and entrepreneurship: Where are we now and where do we need to move in the future?. Entrepreneurship Theory and Practice, Vol. 34. No. 3: 421-440.

Bruton, G. D., Peng, M. W., Ahlstrom, D., Stan, C. V. \& Xu, K. (2015). State-owned enterprises around the world as hybrid organizations. Academy of Management Perspectives, 29(1), 92-114. doi:10.5465/amp.2013.0069

Cabinet of Ministers (2013). Regulation No. 1529 Procedures for organization and financing of health care. December 17, 2013. Available from Internet: https://likumi.lv/ta/id/263457-veselibasaprupes-organizesanas-un-finansesanas-kartiba 
Castaneda, M. A. \& Falaschetti D. (2008). Does a Hospital's Profit Status Affect its Operational Scope?. Re-view of Industrial Organization, Vol. 33. No. 2., 129-159. DOI: $10.1007 / \mathrm{s} 11151-008-9185-9$

Christiansen, H. (2011). The Size and Composition of the SOE Sector in OECD Countries. OECD Corporate Governance Working Papers, No. 5. OECD Publishing, Paris. http://dx.doi.org/10.1787/5kg54cwps0s3-en

Cross sectoral coordination center (2018). State-owned enterprise governance. Riga: CrossSectoral Coordination Centre. Available from Internet: http://www.valstskapitals.gov.lv/en/about-us/

Cross sectoral coordination center (2019). State-owned enterprise's annual reports and databases. Riga: Cross-Sectoral Coordination Centre. Available from Internet: http://www.valstskapitals.gov.lv/en/databases-and-annual-reports/funding-received-from-andcontributions-paid-into-the-state-budget/

Cuervo-Cazurra, A., Inkpen, A., Musacchio, A. \& Ramaswamy, K. (2014). Governments as owners: State-owned multinational companies. Journal of International Business Studies, No. 45: 919-942.

Denis, J. L., Ferlie, E., \& Van Gestel, N. (2015). Understanding hybridity in public organizations. Public Administration, Vol. 93. No. 2: 273-289.

Duggan, M. G. (2000). Hospital Ownership and Public Medical Spending. The Quarterly Journal of Economics, Vol. 115, No. 4: 1343-1373. DOI: 10.1162/003355300555097

Fidler, A., Haslinger, R., Hofmarcher-Holzhacker, M., Jesse, M. \& Palu, T. (2007). Incorporation of public hospitals: A "Silver Bullet" against overcapacity, managerial bottlenecks and resource constraints? Case studies from Austria and Estonia. Health policy, (Amsterdam, Netherlands), Vol. 81. No. 2: 328-338. DOI: 10.1016/j.healthpol.2006.06.007.

Goldberg, E., Grunfeld, L. A. \& Benito, G. R. G. (2008). The performance differential between private and state owned enterprise: The roles of ownership, management, and market structure. Journal of Management Studies, No. 45: 1244-1273.

Harding, A. \& Preker, A.S. (2000). Understanding Organizational Reforms: The Corporatization of Public Hospitals. HNP Discussion paper. The International Bank for Reconstruction and Development, Washington, DC.

Hillman, A. J. (2005) Politicians on the board of directors: do connections affect the bottom line. Journal of Management, Vol. 31. No. 3: 464-81.

Inoue, C. F. K. V., Lazzarini, S. G. \& Musacchio, A. (2013). Leviathan as a minority shareholder: Firm level implications of state equity purchases. Academy of Management Journal, Vol. 56. No. 6: 1775-1801; DOI:10.5465/amj.2012.0406

Jevcuka, L. \& Ketners, K. (2011). Characteristics of management of Latvian state capital companies, problems and possible solutions. Economics and Business, No.21: 39 - 49.

Jiang, Y., Peng, M. W., Yang, X. \& Mutlu, C. (2015). Privatization, governance, and survival: MNE in-vestments in private participation projects in emerging economies. Journal of World Business, No. 50: 294-301.

Kessler, D. P. \& McClellan, M. B. (2002). The Effects of Hospital Ownership on Medical Productivity. The RAND Journal of Economics, Vol. 33. No. 3: 488-506. DOI: 10.2307/3087469

Kovacic, W. (2017). Competition Policy and State-Owned Enterprises in China. World Trade Review, 16(4), 693-711. doi:10.1017/S1474745617000271 
Kuhlmann, E., Blank, R., Bourgeault, I., \& Wendt, C. (Eds.). (2016). The Palgrave international handbook of healthcare policy and governance. Springer.

Laffel, G. \& Blumenthal, D. (1989) The case for using industrial quality management science in health care organizations. JAMA. 262(20):2869-2873. DOI:10.1001/jama.1989.03430200113036

Mettler, T. \& Rohner, P. (2009) Performance management in health care: the past, the present, and the future. In: Business Services : Konzepte, Technologien, Anwendungen. 9.Internationale Tagung Wirtschaftsinformatik (WI 2009). Hansen, H. H, Karagiannis, D., Fill, H. G., edit. Wien, Austria:. 699-708.

Mitchell, S. M. \& Shortell, S. M. (2000). The Governance and Management of Effective Community Health Partnerships: A Typology for Research, Policy, and Practice. Milbank Quarterly, Vol.78. No. 2: 241-289. DOI:10.1111/1468-0009.00170

Musacchio, A. \& Lazzarini, S. G. (2014). Reinventing state capitalism: Leviathan in business, Brazil and beyond. Cambridge, MA: Harvard University Press.

OECD (2016). OECD Reviews of Health Systems: Latvia 2016. OECD Publishing, Paris. Available from internet: http://dx.doi.org/10.1787/9789264262782-6-en

OECD (2017). Corporate Governance in Latvia. OECD Publishing, Paris. Available from internet: http://dx.doi.org/10.1787/9789264268180-en

Pache, A.C. \& Santos, F. (2013). Inside the hybrid organization: Selective coupling as a response to competing institutional logics. Academy of Management Journal, 56(4), 972-1001.

Peng, M. W., Bruton, G. D., Stan, C. V. \& Huang, Y. (2016). Theories of the (state-owned) firm. Asia Pacific Journal of Management, Vol. 33. No. 2: 293-317.

Pirozek, P., Komarkova, L., Leseticky, O., \& Hajdikova, T. (2015). Corporate governance in Czech hospitals after the transformation. Health Policy, Vol. 119. No. 8: 1086-1095.

Rutitis, D., Batraga, A., Muizniece, L. \& Ritovs, K. (2012). Management of corporate identity dimensions in the health care. Procedia-Social and Behavioral Sciences, No. 58: 995-1003.

Saltman, R. B., Durán, A. \& Dubois, H. F. (2011). Governing Public Hospitals. Reform strategies and the movement towards institutional autonomy. European Observatory of Health System and Policies. Observatory Studies Series 25.

Saulitis, E. (2013). Public Corporations, its Legal and Organizational aspects, management and General Interests, in XI International Scientific Conference "Management and Engineering'13". Conference proceedings. Technical University Sofia, p. $1114-1123$.

Qureshi, A. I., Suri, M. F. K. Saad, M. \& Hopkins, L. N. (2003) Educational attainment and risk of stroke and myocardial infarction. Med Sci Monit, 9(11), CR466-473.

Scholten, G. R. M., \& Van der Grinten, T. E. D. (2002). Integrating medical specialists and hospitals. The growing relevance of collective organization of medical specialists for Dutch hospital governance. Health Policy, Vol. 62. No. 2: 131-139.

Stan, C. \& Bruton, G. D. (2013). Theory of the (State-Owned) Firm. ACAD MANAGE PROC 2013, 1, 14904. doi:10.5465/AMBPP.2013.14904abstract

Toninelli, P. A. (2000). The rise and fall of state-owned enterprises in the Western world. Cambridge, UK: Cambridge University Press. 


\title{
UNIVERSITETINIŲ LIGONINŲ REFORMŲ VYKDYMO MODELIO VYSTYMAS
}

\author{
*Māra Pētersone ${ }^{1}$, Kārlis Ketners², Dainis Krieviņš ${ }^{3}$, Ilze Kreicberga ${ }^{4}$, Ingars Eriṇš ${ }^{5}$ \\ ${ }^{1}$ Doc. Dr., Rygos technikos universitetas Kalnciema str.6, LV-1048, Latvija; \\ El. Pašto adresas mara.petersone@rtu.lv \\ ${ }^{2}$ Doc. Dr. BA Verslo ir fnansu mokykla, Kr.Valdemara str.161, LV-1013, Latvija; \\ El.pašto adresas karlis.ketners@ba.lv \\ ${ }^{3}$ Doc. Dr. Paula Stradina Klinikine universitetime ligonine; Pilsonu str. 13, LV-1002, Latvija; \\ El.pašto adresas dainis.krievins@stradini.lv \\ ${ }^{4}$ Doc. dr. Paula Stradina Klinikinè universitetime ligonine; Pilsonu str. 13, LV-1002, Latvija; \\ El.pašto adresas ilze.kreicberga@stradini.lv \\ ${ }^{5}$ Doc. dr. Rygos technikos universitetas, Kalku str.1, LV-1050, Latvija; El. pašto adresas \\ ingars.erins@rtu.lv
}

Pateikta 2805201905 28; priimta 20190630

Straipsnyje nagrinëjami instituciniai susitarimai, perspektyvūs Latvijos universitetinių ligoninių reformoms. Straipsnio tikslas - pateikti Latvijos universitetinès ligoninès valdymo modelį, atsižvelgiant $\mathfrak{i}$ valstybinių įmonių reguliavimą ir jo svarbą valstybinėms ligoninėms.

Atlikta lyginamoji analizè, kurioje nagrinèjami svarbūs universitetinių ligoninių institucinès struktūros veiksniai, ị kuriuos reikia atsižvelgti ateityje, remiantis atitinkamų teisès aktų, politikos dokumentų, EBPO peržiūrų ir PSO vertinimų tyrimais.

Parengti siūlymai dèl pusiau autonominio ligoninès valdymo tobulinimo steigiant stebètojų tarybą ir kuriant naują organizacinę ligoninių formą. Buvo apsvarstytas būsimų mokslinių tyrimų poreikis regioninių sveikatos priežiūros tinklų organizacijų kūrimui Latvijos sveikatos priežiūros sistemoje.

Raktiniai žodžiai: valstybinès įmonès, ligoninès organizaciniai modeliai, valdymas, viešosios ligoninès, sveikatos priežiūros sistema.

JEL kodas: I18; H11; H75; L2O.

* Autorius pasiteirauti 